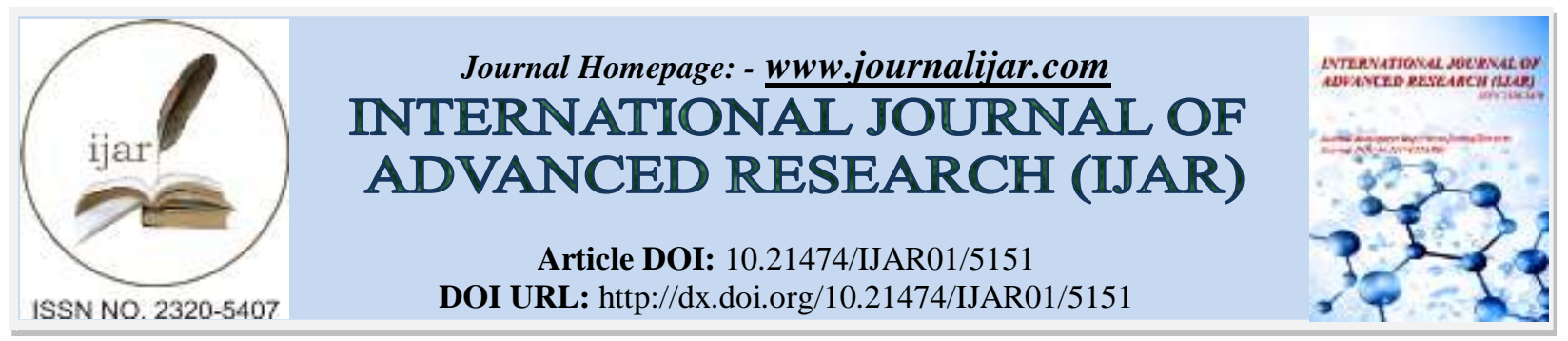

RESEARCH ARTICLE

\title{
CONCEPTUAL REVIEW OF ROLE OF KARAN SANSKAR IN AYURVEDA AND ITS EFFECTS ON FOOD.
}

\author{
Kulkarni Prajkta. \\ Assistant Professor, Sharir Rachana,Tilak Ayurved Mahavidyalaya, Pune, India.
}

\section{Manuscript Info}

Manuscript History

Received: 12 June 2017

Final Accepted: 14 July 2017

Published: August 2017

Key words:-

Ayurveda, Food, Sanskar, Karana,

Guna, Nutrition, Guru, Laghu, Digestion

\section{Abstract}

Ayurveda, being a science of life, consists of wide range of description about food and its various aspects. Food has been referred to as one of the three upastamb has (pillars) of life, viz. Aahar (food), Nidra (sleep), Brahmacharya (abstinence).

The details about the food elements have been narrated thoroughly right from fruits, vegetables up to krutanna varga (cooked or prepared food). As the food has major impact on health, whether it may be staying fit or in production of diseases. A large portion regarding food, its properties, cooking methods is available in samhita granthas (Ayurvedic texts) like Charaksamhita, Sushrutsamhita, Ashtanghruday, Ashtangsangrah and Bhavprakash.

Apart from the individual characteristics of any food, cooking or preparation method also plays a significant role in the digestion of that food without loss of its nutritive value.

Karana sanskar has been described mainly in Charaksamhita in context to the cooking method or the various processes applied while cooking the food. The traditional cooking methods and their impact on food related to karana sanskar have been reviewed in this paper with a few examples of food elements from samhita granthas.

Copy Right, IJAR, 2017,. All rights reserved.

\section{Introduction:-}

Charaksamhita, a major text of Ayurveda has described details of method of preparation of food and its effect on food. The other food related topics include the method of ingestion of food, various food elements with their characteristics. The digestion process depends prakruti (basic nature), desha (region or country), agni (digestive power) of the individual; but also the food which he is going to eat, the method by which it has been made, the processes that it has undergone with. In Ayurveda, 20 attributes or gunas have been described which constitute each and everything on the earth. Among those, food may have guru guna (the food which is heavy to digest), laghu guna (food which is light to digest) and many more.

Each attribute has a certain role in digestion of food. The process, the food has been made with is very important. The nutritive value of the food, the flavor, the taste, the colour, appearance of food everything depends on the preparation or cooking method of the food. All these ultimately lead to the acceptance of the food by the consumer who may be a patient or a healthy individual. Many research works have found definitive role of cooking methods and the above mentioned food related aspects. Ayurveda has already described those in samhita, thousands of years 
ago. Obviously though those have not been measured in terms of numerical parameters of nutrition like calories, no doubt they affect the digestion process and health of the individual or consumer.

\section{Review Of Literature:-}

In Charaksamhita, eight aaharvidhi visheshaayatanas (eight ways of preparation of food) have been described in Vimanasathana .These eight factors are - prakruti (nature of any substance), karan (method of cooking), sanyog (combination), raashi (quantity), desha (region or location), kala (time), upayogasanstha (rules for ingestion), upayokta (consumer).

1. Prakruti-means swabhava, nature or inbuilt characteristics of food or drug. e.g. Masha is guru gunatmaka (Black gram is heavy to digest), Mudga is laghu (green gram light to digest).

2. Karan-Method of cooking or making of food or medicine.

3. Sanyog-combination of two or more than two food or medicinal elements.

4. Raashi-means pramana(quantity).2types-

1. Sarvagraha-combination of all food substances together and total quantity.

2. Parigraha-quantity of individual food substance.

\section{Quantity is important factor for both conditions:-}

1. For getting benefit from food and medicine, it is to be taken in proper quantity

2. Leading to disadvantages in case of taken in improper or inappropriate quantity.

5. Desha-means location or place.It is the place where the food or medicine is produced and distributed.

6. Kala-means time.2types-

1. Conditional-e.g. in case of disease-the phase or duration of disease

2. Seasonal

7. Upayogsanstha-Upayoga-aahara(food)

Sanstha-niyam(rule)

Upayogasanstha means the rules for ingestion of food

8. Upayokta-Means the individual who ingests the food.

The process of digestion also depends on the individual concerning with his digestive power (agni), strength (bala) etc. All the above said factors should be taken into consideration while ingesting the food and digestion process.

Karan is such an important factor which means sanskar (process) that the food is undergone with, during the cooking .It leads to transformation or changes in the original properties of food making it easy for the digestion process. Acharya Charak had mentioned this particular factor which may include the processing with combination of any of the following elements like water(toya),digestive fire(agni), cleanliness or hygiene(shaucha), churning process (manthana), region or place(desha), time (kala) and (Placing the food in particular utensil) bhajana.

In Charaksamhita, the significance of the food elements has been narrated. It has been said that the properties of any substance to be decided by reviewing its original properties, its combination with the other substances of known qualities or properties, the process by which the substance has been cooked with.

a) the churned curd with cream without adding water to it , mixed with cinnamon, cardamom, cumin, jiggery, ginger, bay leaf, Mesua ferrea (nagkesara), the recipe is called as shrikhanda gives health benefits as increasing strength (bala), unctuous, enhances taste.

b) Curd mixed with jaggery also enhances taste,vatanashaka(reduces vata dosha).

While describing the importance of cooking method, Acharya Charak had mentioned that the guru (heavy) attribute gets transformed into laghu(light) attribute and vice versa owing to the cooking method which is being used while preparing the food.

The example of rice cooking has been described for understanding the role of cooking method in Charaksamhita. The rice which is being washed properly, drained, by removing extract, when cooked; the heat is absorbed within rice .This kind of cooked rice, being laghu (light to digest) is helpful in artificial poisoning and kapha vikaras (kapha dosha disorders); whereas the rice which is not washed, without removing extract, letting it to be cooked with the heat and then getting the rice at normal room temperature is guru (heavy for digestion).

Acharya Sushrut had highlighted the importance of cooking method by giving the example of process of roasting or barbequing that the food roasted with coal or being barbequed is light for digestion and increases vata dosha; whereas the food substance which is very thin and being roasted properly becomes light. 
In Charaksamhita, various methods of cooking i.e. karan has been narrated as follows-

1. Toya sannikarsha- combination with water. Nowadays we can consider this context to processes which deals with water like washing, rinsing, soaking, boiling, steaming methods etc.

2. Agni sannikarsha-combination with fire.processes that require fire for cooking comes under this category like steaming,boiling,roasting,sautéing,frying,etc.

3. Manthana-means churning process. It is the method by which curd is transformed into buttermilk. The process leads to transformation or conversion of curd (heavy to digest) into lighter buttermilk, which has been praised for its amazing results in digestion process and relieving various digestive disorders.

4. Shaucha-means hygiene while making food. It is much needed factor for enhancing the benefits of food and to stay healthy and to avoid any pathology.

5. Desha-means place. It may be a country or a region. It is the place where the food is produced or consumed. This factor definitely affects the quality of food due to the fact that the properties of any food substance changes when it is transferred to another place from its original place where it has been cultivated or produced. This ultimately leads to the changes in digestive process of the individual.

6. Kala-means time. It may be the time in context of season or the duration of cultivation, production, ingestion of food substance.

7. Bhajana-means the container or utensil which is being used to keep the food. It also affects the properties of the food.

a) Traditionally, curd is kept in clay pot or glass bowl preferably, rather than any metallic pot or pan to avoid any chemical interaction like copper or iron as it turns toxic if kept in those pots, which is harmful to health.

b) To enhance the absorption of iron, the rotis or vegetables are being cooked in iron pots or utensils in practice.

The variety of cooking methods used today while making the food include the basic elements like fire and water. The processes range from washing, soaking, rinsing to steaming, boiling, roasting, frying etc. Each of these include the varied combination of fire and water without which the food cannot be cooked. Each process results in transformation or change in the basic characteristics of the food right from colour, smell, texture, taste and other nutritive elements in some or other way. The ancient Ayurved texts had described those factors in karan sanskar, affecting the basic nature of any food stuff.

The sanskar (cooking method) results in conversion of the attributes of the concerned food element. In the field of Nutritional science and Dietics also, many research works regarding the changing of properties and the effect of cooking method on the nutrient content of the food had been done so far.

\section{Discussion:-}

Previous research works have shown that there are ways to prevent loss of nutrients of the food by selection of proper cooking methods. That's why the cooking method has deep impact on food in changing the characteristics of the food. Ayurveda specifically recommends these different guidelines while making the food. Though the research has to be carried out thoroughly on this particular aspect, Ayurveda would be helpful in discovering the beneficial effects of variety of cooking methods of the food stuff and their role in the healthy lifestyle and prevention of diseases.

Of course more research work in this field is required to achieve some definite qualitative and quantitative results. The blend of the Ayurvedic concepts and the nutritional science and methodology would surely help to bring out the essence of these facts from both sciences. Research work at the grassroot level has to be carried out for this purpose.

\section{Conclusion:-}

From the above discussion it can be concluded that there is definite role of method of cooking on food. Ayurveda has described all the ailments like prakruti (nature of substance), desha (region or country), karana (cooking method) etc. which have a major impact on digestion of food and changing the characteristics of the food itself. Nutritional science also suggest the various positive effects of cooking methods on food so as to preserve the nutritive contents of the food and to enhance the nutritive quality of the food .More research work is required to explore the other aspects in this field. 


\section{Scope Of Study:-}

1. Karana sanskar (the method of preparation of food) would be definitely helpful to live healthy and balanced lifestyle.

2. Prevention of the disease formation due to improper food qualities and cooking method can be achieved.

3. In case of any disease, following particular guidelines for preparing food would be suggested, which can be helpful in recovery of the patient.

4. For sportspersons, consultation can be done to add in their diet regimen with the food prepared with certain beneficiary effects while cooking.

5. Further research has very much potential in the field of nutrition for finding the definite co-relation and exploring the effects of traditional cooking methods and their effects on food and digestion.

\section{Bibliography:-}

1. Ashtanghhrudayam of Vagbhata,Vidyotini Hindi commentary,Kaviraj Atridev Gupta, $11^{\text {th }}$ edition,Chaukhamba Sanskrit sansthan,Varanasi(India)

2. Ashtangsangraha-Indu tika, Vaidya Anant Damodar Athavale, $1^{\text {st }}$ edition,S.H.Gurjar,Ayurvidya Mudranalaya,Pune(India)

3. Charaksamhita,Ayurvedadipika commentary(Chakrapanidatta),Vaidya Jadavaji Trikamji Acharya,Munshiram Manoharlal PublishersPvt.Ltd., $4^{\text {th }}$ edition,1981(India)

4. Sushrutsamhita,Nibandha sangraha vyakhya,Vaidya Jadavaji Trikamji Acharya,Chaukhamba Orientalia, Varanasi, $6^{\text {th }}$ edition, 1997 (India)

\section{Web References:-}

"A review of the impact of preparation and cooking on the nutritional quality of vegetables and legumes", Adriana D.T.Fabbrin, GuyA.Crosby, International Journal of Gastronomy and Food Science 3 (2016)2-11, www.sciencedirect.com 